\title{
Privatization of State Infrastructure
}

\author{
LeE, SEONG \\ 41st Session, Advanced Center for Administrative Developmtent \\ Graduate School of Public Administration, \\ Seoul National University
}

\section{Introduction}

World's political and economic environments are changing dramatically. Economic bloc is commonly recognized as an international trend and all nations are making the best effort to maximize their benefits. In Korea, the private enterprises obtained good achievements in the electronic and motor manufacturing industries despite international intense competitions. They contributed to the development of country's competitiveness and to the accumulation of wealth.

The success of Korea's private enterprises resulted from the renovation of management and management's determined working principles. By applying the management models of private industries, state enteprises might bring its efficient management.

The majority of state enterprises in Korea was established in early 1970 when GNP per capita was only U\$200. However, some state enterprises, such as Korea Telecommunication, were established in 1980's when the GNP per capita was U\$1,800. Since then, many state enterprises were established, and many, which were competing with the industries, were transferred to private enterprises. At this moment, most of the state enterprises are enjoying the monopoly. As the sizes of state enterprises have grown, there are many problems that need to be solved, especially the rigid and bureaucratic management.

The existing state enterprises frequently faced to solve how to improve the business efficiency through reformation or privatization. Furthermore, relaxation of government 
control and state enterprises' self-reliance should also be considered. In a matter of fact, there is no doubt that state enterprises should be reformed.

\section{The meanings of establishment of state enterprises and their forms.}

State enterprises in Korea were established for various purposes. Korea Development Bank, Industrial Bank of Korea, Korea Trade Investment Promotion Agency, Rural Area Development Co, Korea National Tourist Organization, Korea Security Printing \& Minting Co and National Text Book were established to accelerate the development of Korean industries. In the social aspect, companies such as Korea National Housing Corporation, Korea Land Corporation, and Korea Labor Welfare Corporation were established to improve the quality of people's lives. Korea Electric Power Corporation, Korea Telecommunication, Korea Gas Corporation, Korea Highway Corporation, Korea Water Resources Corporation, Seoul Metropolitan Subway Corporation and Korea National Rail Roads were established not only to improve the general public welfare, but also to improve the competitiveness in domestic and international market by supplying better services. Korea Tobacco and Ginseng Corporation was established to improve national incomes.

By 1993, there are 4 centralized state organizations(Korea National Rail Roads, Postal Service, etc.), 23 enterprise where government possess over 50\% of stocks (Korea Electric Power CO(KEPCO), etc.), 8 government financed companies(POSCO, Korea Exchange Bank, etc.) where the government possess less than $50 \%$ of stocks but being regarded as exclusive stockholder and 102 subsidiaries of government invested

〈Table 1〉 Number of employees and budget limit of central government enterprises (1993)

\begin{tabular}{lccc}
\hline \hline Classification & No. of companies & No. of employees & Budget(billions of Won) \\
\hline $\begin{array}{l}\text { Government } \\
\text { enterprises }\end{array}$ & 4 & 72,613 & 3,844 \\
$\begin{array}{l}\text { Government invested } \\
\text { enterprises }\end{array}$ & 23 & 177,359 & 44,700 \\
$\begin{array}{l}\text { Government financed } \\
\text { enterprises }\end{array}$ & 8 & 42,359 & 10,934 \\
$\begin{array}{l}\text { Subsidiaries of } \\
\text { invested organization }\end{array}$ & 102 & 69,449 & 9,012 \\
Total & 137 & 361,820 & 68,492 \\
\hline
\end{tabular}


〈Table 2) Number of employees budget limit of local government enterprises(1993)

\begin{tabular}{lccc}
\hline Description & Number of comparies & Number of personnel & Budget(billions of Won) \\
\hline Waterworks & 76 & 1,965 & 1,752 \\
Sewerage system & 13 & 1,023 & 301 \\
Local medical institution & 34 & 5,091 & 224 \\
Public development(direct) & 59 & 1,081 & 3,787 \\
$\begin{array}{l}\text { Industrial development } \\
\text { (Indirect) }\end{array}$ & 3 & 836 & 2,746 \\
Joint company invested by & 6 & 363 & 54 \\
the private and state & 6 & 8,646 & 881 \\
Other state enterprises & 197 & 19,005 & 9,747 \\
Total & & & \\
\hline
\end{tabular}

organizations. So the total numbers of state enterprises are 137.

Although the local government's enterprises have fewer employees and less amount of budgets than the central government's enterprises, the numbers 197. They offer water supply, sewerage system, medical services, Metropolitan Subway Corporation and other invested companies. There are 197 cental and local government enterprises with 380,000 employees and 78 trillion Won budget limits per year.

\section{Necessity and role of state enterprises from the view of public economy}

From the past, it has been shown in foreign countries that there are 5 patterns in the role of state enterprises influencing to the public economy. The first pattern is shown in socialist countries in which the state enterprise gives an overwhelming influence to public economy. The second pattern is shown in developing countries in which significant amount of nation's economy has been influenced by state enterprises. The third one is Japanese pattern in which during the development stage a large amount of nation's economy was influenced by the state enterprises, but its influence decreases as the economy grows. The fourth one is the European pattern in which state enterprises' role gradually increases as the society becomes to a welfare state. Finally, there is North American pattern in which the influence of state enterprises was insignificant. For example, most of the public services in USA are offered by the contract between the state and public enterprises and the important industries such as an energy has been owned by the private enterprises. 
In Korea, the role of state enterprises is similar to that of Japan's, and although many state enterprises privatized in 1980s, state enterprises' role and influence and still significant to the public economy. In recent years the value-added ratio of state enterprises' GDP in reached 9.4\%, and as the structure of Korean industry becomes more diversified and more specialized, state enterprises' influence on the related industries also becomes more significant. State enterprises' value added is essential to certain industries; state enterprises hold $97 \%$ of electric industry, $86 \%$ of telecommunication industry, $65 \%$ of steel industry, $100 \%$ of road construction.

〈Table 3) The ratio of value added of state enterprise sector to GDP(\%)

\begin{tabular}{lccccc}
\hline \hline Description & 1975 & 1980 & 1984 & 1986 & 1990 \\
\hline $\begin{array}{l}\text { Value added of state enterprise/GDP } \\
\begin{array}{l}\text { Value added of state enterprise/GDP } \\
\text { of non agriculture and forestry }\end{array}\end{array}$ & 11.3 & 9.1 & 9.7 & 9.0 & 9.4 \\
\hline
\end{tabular}

source : Korean state enterprises' improvement of management administration and privatization policy, Dae Hee Song, January 1994

〈Table 4) The percentage of fixed asset held by state enterprises in the domestic market(unit : \%)

\begin{tabular}{llllc}
\hline Year & 1980 & 1984 & 1986 & 1990 \\
\hline Ratio & 27.6 & 20.7 & 15.7 & 8.9 \\
\hline
\end{tabular}

source : Korean state enterprises' improvement of management administration and privatization policy, Dae Hee Song, January 1994

〈Table 5) Industrial correlation of state enterprise sector

\begin{tabular}{c|c|c|c|c}
\hline \multirow{2}{*}{ Year } & \multicolumn{2}{|c|}{ Correlation coefficient of front line industry } & \multicolumn{2}{c}{ Correlation coefficient of rear line industry } \\
\cline { 2 - 5 } & State enterprise sector & All industries & State enterprise sector & All industries \\
\hline 1980 & 0.6002 & 0.5144 & 0.6622 & 0.5579 \\
1984 & 0.6708 & 0.5122 & 0.6508 & 0.5471 \\
1990 & 0.6025 & 0.5025 & - & 0.5723 \\
\hline
\end{tabular}

source : Korean state enterprises' improvement of management administration and privatization policy, Dae Hee Song, January 1994

In 1986 state enterprises held $28 \%$ of fixed assets, however, in recent years it dropped to $9 \%$ due to the increase in the fixed asset held by private manufacturing 
industries. $70 \%$ of state enterprises' fixed asset is concentrated in machinery equipment sector, and this shows that capital intensive industry is important in the state enterprises.

\section{The problems proposed during the management of state enterprises}

In the past state enterprises contributed significantly to the development of Korean economy, however, in the recent years private enterprises became more important to the national economy than state enterprises. Due to provisions of internationalization and opening of markets, private enterprises are endeavoring to upgrade the competitiveness. Many people say it is necessary for state enterprises to renovate their management so that they can serve citizens better and keep up with private enterprises. In case of state enterprises, the management policies such as refraining from the rise of public fare and restraints of service personnel's salary can save government budget and can be the tool of sharing the burden of private sector.

Compared to the past, the size of Choebol groups and state enterprises have become enormously big. The staffs in the government and the academy often point out Choebol groups' disordered and diversified management and state enterprises' loose management. Choebol groups claim that it is just a management rationalization process to decrease the business risk. In the state enterprises, people argue that their productivity per capita increased despite the increase in the number of employees.

When state enterprises were first established, their goal was to improve efficiency, but people say now that they have been inefficient as the followings:

\section{Deficiency of profit maximization}

State enterprises need to understand the idea expenditure minimization to achieve the efficiency and profit maximization, and they need to promote the business plan giving priority to investments and return on investment. However, from the procedure of business and price selection of state enterprises, their profit maximization is deficient. State enterprises usually have a tendency to justify their sluggish performance, and the loss amount is often transferred to the government deficit. In many cases, the decrease in the profit of state enterprises is the result of the government's unfavorable economic policy and the intervention of political authorities.

\section{Inefficiency caused by the bureaucratic management in state enterprises}

Management of state enterprises became rigid as they grew larger from small size 
enterprises. This change causes the complication of business procedure as well as the time loss. As a result, a staff member faces problems adapting himself to the new business environment, and the service to client deteriorates. Unlike private enterprises, state enterprises are common properties. Although the public service staff claims that everyone is an owner, in other word, this can also mean that there is no owner. This causes state enterprises to operate business according to budget maximization and not profit maximization. It occurs occasionally over investment or over employment.

\section{Government regulations and controls}

Although there is a board of directors to promote the self-reliance of state enterprises, the important management policy is decided by the directors of government offices such as the competent ministry and ministry of finance. The service cost and the quantity amount supplied by state enterprises are frequently controlled by the government, and in such circumstances the state enterprises can face a management oppression or a constant deficit. It is quite difficult for them to make inroad into the new business because of the various regulations from the governments such as a budget control and an incorporation issue. The inefficiency of management arises due to time loss cause by overlapping audit or by the object of the board of audit and inspection. As a result, the state enterprises restrain themselves from developing new businesses, and discourage themselves from working hard due to the possibility of being pointed out from the audit. Their attitude toward their work is far from being aggressive management.

\section{Propelation examples and problems from the privatization of the state enterprises}

Privatization is one of state enterprises' schemes to improve their productivity. People usually consider that privatization process would be transferring the legal ownership to a private sector by selling the stocks of the state enterprises. However, as mentioned in the previous page, the objective of privatization in Korea was to increase economic efficiency through competition. Fourthermore, transfer of company's subjectivity is considered more important than the transfer of the ownership. If the government regulates the state enterprises even though government possesses less than $50 \%$ of the stock, then it is difficult to say those enterprises are privatized. In the <table 6>, we can see that the role of government decreases as it goes to the lower right corner. The above two columns in the upper hand of the table can be categorized as state enterprises, and the two lower columns can be categorized as 
〈Table 6) Types of privatizatin by state enterprises

\begin{tabular}{c|c|c}
\hline $\begin{array}{l}\text { Business } \\
\text { subjectivity }\end{array}$ & \multicolumn{1}{|c|}{ Government } & \multicolumn{1}{|c|}{ Private } \\
\hline Government & State enterprises & $\begin{array}{l}\text { Partial Privatization } \\
\text { Existence of government's re- } \\
\text { gulation(e.g.Electricity and tel- } \\
\text { ecommuniction companies in } \\
\text { France and UK) }\end{array}$ \\
\hline Private & $\begin{array}{l}\text { Goverrment owned enterprises } \\
\text { that supply products and ser- } \\
\text { vices to the public. In this } \\
\text { case there is a contract betw- } \\
\text { een the state and the private } \\
\text { company(E.b. waste disposal } \\
\text { service }\end{array}$ & $\begin{array}{c}\text { liberalization) } \\
\text { libationalization, }\end{array}$ \\
\hline
\end{tabular}

Source : Study of privatization, KDI, Shin II Kang, 1988

private enterprises

Complete privatization means that $100 \%$ of government owned stock would be sold to the private enterprises and then the management would be carried out by the private company. The following paragraphs show various types of the methods of privatization.

One can transfer the government owned equity by selling stocks to the private through and open auction or through a stock market. In case of a closed-door corporation, one can use the outside market. Although a complete privatization has not been occurred yet, there are many cases where the companies are being partially privatized. Companies such as POSCO, KEPCO, Japan's telecommunication corporation and Great Britain's airline companies are good examples of partially privatized companies.

It is advantageous to use the method of selling stocks. It is easy to reach the adequate price since it is easy to make a compromise with the buyer, and it can privatize various kinds of industries through stock market. In addition, if the government faces budget deficit, it can also supplement them by controlling the process of privatization.

There is another way other than using the method of privatization through sales of stock. If private enterprises manage the production of commodities or services through a contract without transferring the ownership, then this can also be categorized as privatization. That is because the management initiation is transferred to the private 
sector. In the United States, waste disposal service, ambulance operation, road cleaning, management of parking place and museum services are carried out by this system. According to the aspect of contract, it can be divided into franchise and leasing system.

Franchising system can be applied to following situations. KEPCO can manage power plants by giving its priority to investment. Telecommunication enterprises give its priority to profit maximization during the business in Korea or in abroad. The banking organization gives its priority to profit maximization through branches or by regional areas.

Leasing can cause a deterioration of competitiveness. Because of a large amount of fixed charge, it makes a company appear to have much debt, and it is quite difficult for the borrower to take. This system can be applied to protect special facilities and technologies in state enterprises.

During privatization, if the government does not approve a majority stockholder and continues to regulate the management of enterprises such as banks in Korea, then this is not considered as a true privatization.

\section{Privatization cases in the world}

The privatization of state enterprises is a trend in the world. Since the Second World War, many countries nationalized their private enterprises and many state enterprises were established. However, since 1980s, countries as UK, France, Italy, South America and Japan have promoted privatization, and the objective of the privatization was to minimize the budget deficit and to renovate the economic structure. The following paragraphs explain the background, objective and method of privatization throughout the world.

In the early 1980s, South American countries like Argentina and Brazil faced an economic crisis due to the 1 st and 2nd Oil Shock. They faced an increase in the financial deficits caused by inefficient management of state enterprises. They experienced a hyper-inflation that they were incapable of paying back foreign debts. During this period, they started promoting the privatization. In the early 1980s. the objective of privatization was to reduce the foreign debts as well as minimizing the budget deficit. The objective of privatization gradually changed to the renovation of the structure of the economy, such as the improvement of state enterprises' efficiency and reconstructing the business structure of government and private sector.

The developed countries such as Great Britain, France and Japan first started privatization during 1980 s to improve the economic efficiency. Before 1980 in Great Britain, state enterprises' role was very important to the national economy, and intense 
nationalization of enterprises occurred by the Labor Party. However, after Thatcher became the prime minister, she accelerated the policy of promoting the privatization of state enterprises to increase the economic efficiency and productivity. In France, after the Republican Democratic Party came to power in 1986 they started promoting privatization based on open market economy priniciple.

The developing countries such as Malaysia. Thailand, and other south East Asian countries started privatization to renovate the financial problems. The objectives were such as to decrease the government budget deficit and trade deficit, and to increase the productivity.

Each country has different causes for a privatization. South American countries like Mexico, Chile and Argentina promoted privatization not only in the manufacturing sector, but also in the public service sector such as telecommunication, and electricity and gas. They allowed foreign enterprises to invest in the public service sector, to reduce the foreign debt and the budget deficit. In Argentina, almost every public service sector such as energy, transportation, telecommunication and banking are in the process of privatization. From 1989 to 1993, 57 state enterprises' equities and 27 of state enterprises' management rights fell into to the private hands. In Brazil, the government first promoted privatization in the manufacturing sector. Since 1994, the government farther included the public service industries such as telecommunication, mining industry and water-power generation.

The countries mentioned in the above paragraphs on the whole succeeded in privatizing manufacturing sector. Privatization gave the changes in the economic environment, abolition of price control and deregulation. In other hand, privatization also brought some problems. The number of unemployment rose due to the lay off, and since the reinvestment from the profit totally depends on the private owners, many people think it would be easier for state enterprises to reinvest. Also people believe that the quality of public service will deteriorate due to monopolization of private enterprises. Furthermore, in South American countries, since the foreign companies acquired the public service industries and those services were provided by the foreigners, people saw the situation as the defamation of the national economy.

From the above paragraphs, we can summarize privatization in abroad. First, in almost every country, the manufacturing sector was first privatized. Second, after the manufacturing sector, it was banking, telecommunication, and energy(electricity, gas) sector, but many of them are continuously regulated by government. Third, road, railroad, harbor, airport and water supply were the final industries privatized or planned to be privatized for the last stage. Most of the countries are operating these industries as a form of state enterprise. 


\section{The present condition of the privatization of state enterprises in Korea}

In Korea since late 1960 s, there has been a renovation of economic structure, and many state enterprises have been privatized. There were three promotions of privatization schedules in 1968, 1980 and in 1987. Since 1993 the new government came to power and the government farther promoted privatization to renovate the structure of economy and to increase its efficiency.

(1) Privatization in the past

From 1968 to 1978, the government partially or completely privatized 10 state enterprises through selling its owned equity or through investment in kind. They are Korea Transportation('68. 7), Korea Sea Transportation ('68. 11), Korea Ship Building Co('68. 11), Korean Airline('69. 3), Korea Mining Co('71. 6), Korea Salt Co('71), Commercial Bank('73. 2), Korea Fisheries Developing Co('73. 11), Inchon Steel('78. 6), Korea Insurance $\mathrm{Co}(' 78)$.

From 1980 to 1983, Yukong('80. 12), Korea Dredging Co('82. 2), Hanil Bank('81. 7), Korea First Bank('82. 9), Seoul Bank('82. 9), Cho-hung Bank('83. 3) werde privatized as a part of measurement of the renovation of economy. Among them the four city banks were privatized by sales of stock and an official public tender. These banks, however, have no majority shareholders due to the limitation of stok possession set by the government. These banks are still regulated by the government.

In 1987, a large scale of privatization plan was promoted to redistribute the income. However, it has not reached the goal, and it has been delayed since then. Companies such as POSCO, KEPCO, Korea Telecommunication, Korea Tobacco and Ginseng Co, Citizens \& National Bank, Industrial Bank of Korea and Korea Exchange Bank were planned to be privatized through sales of stocks to public. However, due to the stagnation of the stock market, stock prices were held in check. As a result, it provoked th civil appeals of the public, especially the farmers, and it interrupted the selling stocks and privatization process.

We can examine the gains and losses from the process of privatization in Korea. The gains are the formation of new environment searching for the profit maximization through management responsibility and business activation by the highest executive, and the elevation of productivity. It was done through cutting the cost price and the introduction of incentive system. As a result, these gains increased the management efficiency. Furthermore, through creation of owned assets and stengthening the internal reserves, it provided conditions to renovate the financial structure. Also on the other hand, one could decentralize the business risks by opening up the new market and by diversifying marketing through the strengthening of sales promotion. 
There were also losses from the process of privatizatin especially in sea transportaton and ship building industries. They suffered from the serious competitions and as a result, their profits decreased considerably. Due to a large number of enterprises entering into the market, there were more supplies of commodities and services than actually needed. There were cases in which companies dropped out from competition due to the lack of management skills. Furthermore, the continuous interference by the government also hampered their self-reliance.

If we look at privatization schedule in the past, in 1968 the first privatization served the purpose of transferring the ownership and the management rights from state to private hands. Companies as Korean Transportation, Korean Airline, and Oil Co are the cases in which privatization were carried out successfully. However, pivatization schedules of financial institutions in 1980 or the other privatization schedule in 1987 were merely a partial privatization, and the continuous interference by the government indicates that it was not a true privatization.

(2) Privatization schedule of state enterprises in 1993

After beginning of civil government, the fourth privatization schedule was scripted to accomplish the national guide line of constructing new Korea. There was an order from the president to prepare a plan of restructuring state enterprises on October 5, 1993. The committee of judging government investment confirmed the principles of selecting the objective privatization enterprises on October 21, 1993. In January 1994, there was an establishment of privatization schedule according to competent ministry department. On February 18, 1994, detailed scheme of privatization plan was settled at the board of privatization promotion.

We can see from the bases of privatization schedule in 1993 that the goal to increase management efficiency by transferring the management right to private hands. Privatization depends on the situation of stock market, and the privatization should not be delayed due to the instability of stock market. Privatiztion can be promoted by applying the principles of competition in diversified ways such as sales of stocks at stock market, outside sales of through a public tender. In case of conglomerates, the fundamental rule is that they can only be permitted to take part in privatization within the limit of credit However, by considering the characteristics of their industries and their organizations, the exceptions can be permitted. In addition, regarding the employees of state enterprise, the stabilization of employment should also be considered.

The basic rules in selecting state enterprises as to promote privatization by the government are as follows. The companies that accomplished their objectives of establishment; subsidiary companies in which their working porinciple does not 
correlate with the mother company; a company participating inappropriate business acivity, or a company with a large deficit. There are total of 61 companies with the above cases and they are as follows:

- Government invested companies(8) : Citizens Bank, Bank of Small-size Industry, Korea Housing Bank, National Text Book, Korea Tobacco and Ginseng Co, Korea Gas Co, Korea National Tourist Organization, Korea Labor Welfare Co

- Government financed company(1) : Korea Exchange Bank

- Subsidiaries of invested companies(52) : Namhae Chemical Co, Korea Fertilizer $\mathrm{Co}$, Korea Tungsten $\mathrm{Co}$, etc.

During the privatization propulsion in 1993, there were two cases in which the state enterprises privatized. First one was Bundang Station Management Co (management of the subway station), the subsidiary of Korea Land Co that was transferred its management rights to a private sector through process of a pulblic tender. The other one is Freeway Installation Management $\mathrm{Co}$ that was managing the service areas of the freeway in Korea as subsidiary of Korea Highway Corporation. It was privatized through public competition as a form of leasing the facilities. However, the plans of privatizing 61 state enterprises from 1994 to 1998 seem to be unreasonable. We must remark the cases of Great Britain and France where despite their active progress in promoting privatization, only four state enterprises were privatized per year. As a result, unless controlling more actively processes of privatization, government may lose its confidence in the whole privatization scheme. People point out that the government is rushing the privatization process without having enough research and without a full preparation, and without enough detailed information nor any good strategies. When selecting state enterprises to promote privatization, people point out that the government may have an absurdity as the government make decisions without a full examination of enterprises. People also said the government considered the preference of big private enterprises rather than considering the characteristics of industry. People say only the small companies were chosen that the privatization would bring us a little national economy effect. Furthermore, the government put emphasis on government invested financed company that is already in competiton with the private enterprises. Also, there are people who are concerned with the possible dispute between labor and capital inside the selected companies.

In February 1994, the privatization schedule was settled, and during the process of selecting the third mobile-phone service company in the first half of 1994, people criticized the cheobol-oriented government policy. So in July 1994, the government announced a counter-plan of privatization. It says that the government will decide by the end of 1995 the times and methods of privatizing large monopolistic state enterprises. They were Korea Gas Co, Korea Tobacco \& Ginseng Co, and Korea Heavy 
Industry: In case of Korea Gas Co, the interim report of consultant was presented indicating that it would be better selecting the majority stockholder allowing to offer new stocks for public subscription. The selecting should be based on the competition of public tender and the assessment on the business plan issued though the procedure of tender. This plan, however, is withheld to the end of 1996.

\section{Pros and Cons on the privatization of the state infrastructure}

\section{An issue of the privatization of the state infrastructure}

Until now, we looked at the trend and the situation of privatization in Korea and other countries. In Korea, privatization first started in the manufacturing industries followed by the financing and public service industries. Four commercial bnaks (Hanil Bank, Korea First Bank, Seoul Bank, and Cho-hung Bank)and Industrial Bank of Korea, Korea Exchange Bank and Citizens \& National Bank are competing with the private banks. However, theses banks have no owners and the interference of the government still exists. Due to the opening of financial market, the renovation of those banks is inevitable. Korea National Housing $\mathrm{Co}$ is already meeting competition with the private enterprises. Korea Land $\mathrm{Co}$ is also in competition, and if the business of housing development is practiced by the private enterprises, the role of Korea Land Co will decreases significantly. Majority of people support privatizing Korea Tobacco \& Ginseng Co, National Text Book, Korea National Tourist Organization and Korea Labor Welfare Co. In case of Korea Security Printing \& Minting Co, Korea Trade Investment Promotion Agency and Rural Area Development Co most people insist that these enterprises should remain as state enterprises. The logic of pro and cons on the privatization of the state infrastructure is as follows:

The role of state infrastructure is very important to the development of all industries as it supplies all indirect capital to industries. State infrastructure includes energy industry that supplies gas and electricity, social overhead capital, such as telecommunication, road, railway, airport, harbor and dam, heavy chemical industry and steel industry. We can also include motor industry and telecommunication industry into state infrastructure category. These industries are being well-made active by private companies. In telecommunication sector, the local telephone service is still in monopoly but the long distance telephone service and mobile-phone services of the state enterprises are competing with that of private enterprise. Therefore, motor, chemical, long distance telecommunication and mobile-phone service are considered to be preferably privatized.

Companies like POSCO, Korea Telecommunication, KEPCO, Korea Gas Co, Korean 
National Rail Road, Korea Maritime and Port Authority and Korea Water Resources Co belong to a monopolist group. It is too much of a risk for private enterprises to take over businesses, because the costs of investing in these industries are enormous. Among these enterprises, Korea Gas $\mathrm{Co}_{0}$ is the only industry that the new government is promoting to privatize. As explained in the earlier pages, the process of privatization of Korea Gas Co has been delayed for a year. Privatization schedule is being disturbed by the interference of government and some dishonest business persons.

Regarding privatization of state infrastructure enterprises, we can raise some controversial questions. First, is privatization the only scheme to improve productivity and efficiency? Second, is it very necessary to privatize state enterprises even if the market is not competitve? Third, is it preferable to let the conglomerate acquire state infrastructure? Will the acquisition be as public stock to reduce the burden of government? Fourthly, in case the private enterprises acquire the monopolistic state infrastructure, the public may not benefit the service they had before because of private enterprises' profit oriented management. In this case will the government interfere? Finally, can we solve the social problems caused by lay-off during privatization?

\section{Pros on the privatization of state infrastructure}

From the paper (Ownership and Performance in Competitive Environments, Journal of Law and Economics, 1989) by Boardman and Vining, it suggests that private enterprises are more efficient than state enterprises. On the paper of Public Ends and Private Means 1985, Donahue points out that the privatization process can bring efficiency not because of the transfer of ownership to the private, but because of the business's activity in a competitive market. He also points out that privatizing state enterprises is a necessary procedure to improve the efficiency although it is not sufficient. The logic that suggests privatization is necessary is as follows:

(1) Increase in economic efficiency

It is easier to apply the market economy to the business if the ownership falls in private hands, and it can also develop the stock market by supplying large amount of blue-chip stocks.

\section{(2) Increase in profit}

Private ownership of enterprises promotes profit maximization. Shareholers can contribute to efficiency of business through their activities and their opinions based on 
stock price index. Also, based on the motivatin of profit maximization, the owners can improve profit through diversifying business domains and opening up new market.

(3) Existence of owner

Common ownership of property creates free-riding problems and causes inefficiencies to industry. "Everyone is an owener," may means "there is no owner." This can bring an inefficiency. Therefore, through privatization, it can minimize the agent-agent problem and thus increase efficiency.

(4) Granting incentives

People understand that private enterprises are more likely to be bankrupted than state enterprises and they should do more efforts for avoiding bankrupt. Through privatization, it can eliminate "rent seeking behavior" in which people in state enterprises tend to seek higher salaries and bonuses than people in private enterprises. By applying the incentive system to private enterprises, it will increase the productivity.

(5) Coping with the economic environment change

Because the most state enterprises are giants, they have vertical organization and bureaucratic management system. These cause delay of decision making and government interfere together with intervention from the political people. Such problems result inefficient management system, but it can be improved through privatization. According to diversity of consumers' needs and patterns, and high level of industrial system and heavy market competition, it would be more appropriate to apply private management system than bureaucratic management system.

(6) Increase in Government profit

From the sales of stock, government can temporarily increase the tax revenue decreasing the production of government bond and, therefore, it will be able to lower the burden of people's tax payment.

\section{Opposite opinion against the privatization of the state infrastructure}

The forms of privatization of state enterprises can be different due to the difference in countries' environment and characteristics of business. People assume that the transfer of ownership from government to private brings the efficiency to enerprises. However, the following conditions must be statisfied to certify its efficiency.

First one is the problem of the government regulation after privatization. Unlike 
state enterprises, the objective of private enterprises is to maximize profit. Government, however, will continue to interfere with the enterprises to maintain their characteristics of benefiting public. Therefore, with the existence of regulation, the increase in efficiency will be uncertain. As mentioned before in this paper, Donahue's paper(Public Ends and Private Means, 1985) suggests that the efficiency of the privatized enterprises will increase as a result of competition. Caves and Christensen(The Relative Efficiency of Public and Private Firms in a Competitive Environment, Journal of Political Economy, 1980) say there is no evidence that state enterprise is inferior to private enterprises when comparing their achievement in railroad business.

State infrastructures as electricity, road construction, gas, harbor, railroad and telecommunication will face problems in promoting privatization because after the privatization, it will be difficult to prohibit their monopolistic enterprise(nationwide or locally).

(1) Formation of capital and withdraw of investment

Public service and social overhead capital sector are capital intensive, and since their burying costs are high, in the early state of business development. It requires an enormous expense, and a long time to draw in capital. Unless the ill minded thoughts, such as "company dies, but the owner will live," disappear, it would be a risk to entrust state infrastructure industries to the private enterprises. Afler privatization, government will concern the private enterprises when they need the investment on additional demand. In case the investment is not facilitated, it may occur to deteriorate the service for a long time. Also being unable to catch up with the economic development, social overhead capital sector may also deteriorated.

(2) Concentration of economic power on specific cheobol enterprises(weak method)

If the purpose of privatization is to improve efficiency by introducing an owner to company, then it is difficult to privatize the enterprises tht are formed with public stock. Therefore, to introduce an owner to the company, it is inevitable to transfer the ownership to a specific enterprise. However, since most of state enterprises are big, it is unrealistic for small-to-medium-sized enterprises to take part in privatization. As a result, cheobol can only acquire the state enterprises, and in this case it provokes the concentratoin of economic power on specific cheobol enterprises.

(3) Monopolistic character of state infrastructure industries

The cardinal point of privatization is the introduction of economic principle. However, the state infrastructure industries are monopolies that it is impossible to 
create a competitive environment.

Also it is unreasonable to create artificial competitive environment. In cse of the artificial competitive environment, this will not be substantial because the identical commodities and services can not be selected by consumers. As we can see from table 7, only a few industries including steel, long distance telephone service and mobile-phone service have a possibiltiy creating competitive environment. Other industries of state infrastructure are locally monopolies, and intensity of monopoly can only be eased in a certain extent. Therefore, it is difficult to increase economic efficiency by means of privatizing state infrastructure are locally monopolies, and intensity of monopoly can only be eased in a certain extent. Therefore, it is difficult to increase economic efficiency by means of privatizing state infrastructure industries and create the competitive environment. In case of public service and social overhead capital industries, they are fundamental services offered by the government, and they influence tremendously to other industries. Furthermore, due to the characteristic they have as a net-work, they need a regulation and should be provided by the government.

(4) Tyranny of monopolistic private enterprises

Similar to monopolistic character of state infrastructure industries, if monopolistic enterprises are privatized, it will create the monopolistic private enterprises. In this case the private enterprises will endeavor to maximize their profit while government will regulate them to increase the benefit of public. In case the government regulate the price of commodities and services of the private enterprises, these enterprises can face a deficit, and eventually it can go bankrupt. In these circumstances, the government will fall into a dilemma of saving these enterprises because the bankruptcy will affect enormously to all industries. To save them they need to give various kinds of support such as a financial aid or financial privileges. Therefore, privatization is unreasonable.

(5) Weakness of Capital market (Weakness of approaching measure)

The government experienced the social problem caused by the sharp drop of stock price in 1987 and 1988. It is supposed that Korean capital market is not stong up to now, but it can be possible to be solved, according to the enlargement of economy size and the development of capital market. More serious problem is that it is not easy to find private companies of which financial status is strong enough to take over the state enterprises. 


\section{Conclusion}

The gist of the pro's logic for the privatization of the state enterprises is that it is anticipated that the effectiveness and the profitability will be increased if a private company controls them. The con's logic is that there will be no help to improve the management effectiveness through the privatization if the circumstances of competition are not arranged regarding the concerned industry. To preserve from the public benefit under monopolized market situation, they cannot transfer to the private companies. In addition, due to the undesirable management measures from the owner and the poverty of capital market, it is too early to privatize now such large state enterprises. Even though the world-wide trend is to privatize the state enterprises gradually it would be better to reestablish the basic measures in choosing the object enterprises.

\section{State enterprises, that compete against private enterprises, should be privatized.}

However, the subjects to be privatized should be selected according to the enterprises' size, financial status, ralated market structure and produce. Especially industries showed in the $\langle$ Table 7$\rangle$, such as a long distance and a mobile-phone service have possibilities to improve the management efficiency through grafting the private company's skill.

\section{It is necessary to prepare the ground of competitiveness for the sake of its} improvements before privatization

To minimize the possible shock form privatization, it is recommended to prepare competitiveness structure before visibility of privatization. For the readjustment of state enterprises' business structure it should be considered necessary to deal well with the additional demands by leading the private capital inducement and by allowing the private enteprises to participate in the field of state infrastructure. From the measures, it is not totally anticipated for the market competitiveness infrastructure. From the measures, it is not totally anticipated for the market competitiveness structure to establish $100 \%$ freedom from regional and technical monopoly, but to some extent the indirect effect on competitiveness and the restraining function among regions during deciding prices. It is not natural to privatize all state enterprises especially in the field of energy, transportation and dam, dut it is meaningful to prepare the privatization according to the change of economy atmosphere. 
〈Table 7> Competitiveness of infrastructure between the state and the private enterprises

\begin{tabular}{|c|c|c|c|c|}
\hline \multirow{2}{*}{$\begin{array}{l}\text { Kind of } \\
\text { industry }\end{array}$} & \multicolumn{2}{|c|}{ Competitiveness } & \multirow{2}{*}{$\begin{array}{l}\text { Competitiveness in } \\
\text { creating public capital for } \\
\text { additional demands }\end{array}$} & \multirow{2}{*}{$\begin{array}{l}\text { Possible industries being } \\
\text { anticipated } \\
\text { competitiveness }\end{array}$} \\
\hline & present & future & & \\
\hline $\begin{array}{l}\text { Electric } \\
\text { Power }\end{array}$ & Monopoly & Monopoly & Locally Monopoly & Oil, Gas \\
\hline Gas & Monopoly & Monopoly & Locally Monopoly & Electric power, Oil \\
\hline Steel & Almost Monopoly & Competition & Competition & None \\
\hline Road & Monopoly & Locally Monopoly & Locally Monopoly & Railway, Airport \\
\hline Railroad & Monopoly & Locally Monopoly & Locally Monopoly & Road, Airport \\
\hline Harbor & Monopoly & Locally Monopoly & Locally Monopoly & Railroad, Road \\
\hline Dam & Monopoly & Competition & Locally Monopoly & None \\
\hline $\begin{array}{l}\text { Long distance } \\
\text { telephone \& } \\
\text { Mobile-phone }\end{array}$ & Competition & Competition & Competition & None \\
\hline $\begin{array}{c}\text { Local } \\
\text { telephone }\end{array}$ & Monopoly & Locally Monopoly & Locally Monopoly & None \\
\hline
\end{tabular}

\section{It is important to transfer all management rights eventually when privatization is} done

The privatization that all rights are not transferred from state has only effect to increase government financial income. Regarding to this, government should deregulate the related laws, foundation grounds and sell whole stocks to find very private ownership. Government sold 34.1\% of POSCO and 21\% of KEPCO stock in 1987 as the third privatization schedule, but it is difficult to say "privatization" as long as government holds $51 \%$ of stocks. The banks tht have no owners cannot improve their efficiencies in management due to the government interference. On the other hand, Korean Air, Korean Transportation $\mathrm{Co}$ and Oil Company have shown good performance under the control of private owners.

It is wrong to say 'we have to proceed privatization, privatizing the state enterprises is difficult,' or 'it is world-wide trend to privatize, so we have to follow it' Current situation in whole industries, financial status and business character will be important factors to decide the time \& method of privatization. The fourth privatization schedule of 1993 should be revised from the point of view whether it has any unreasonable matters in selecting the objective state enterprises. It should be avoided to find consistent proceeding in hurry and to do only for the sake of privatization. 
It would be the most desirable way if the state enterprises are able to find their efficiencies through the manner of rushing into market economy system and completing privatization under competitiveness atmosphere with adaptation of management skill created by the private sector. It is practically difficult to take over big state enterprises by capital caused by the under developed domestic capital market. In case that private enterprises are able to undertake state enterprises, the competition atmosphere is not formed. So the private enterprises will enjoy monopoly that is not a desirable situation.

Therefore, as for the most of the state enterprises of national infrastructure, it is much better to maintain the status. From the level of government, budget should be allocated properly for upgrading investment efficiency. Furthermore, system improvement for the self-reliance has to be raised. It is also necessary to deregulate restrictions for participation of private capital and to improve control system. Inducing private cpaital means the competition among the related industries and the whole country basis monopolization that seems to be changed to region basis monopolization. Those will make firm ground to find successful privatization in the future.

Up to now, the competition relations in the same industry fields of state enterprises are analyzed. However, it is possible to consider the privatization plan; how the competition in the similar industries will be induced. If the compectition of price and convenience in the similar industries, such as between electricity and petroleum or rail road and road transportation, have some effects on the distribution of demands, this kind of privatization can be considered to as alternative.

Since having been settled soundness of industry culture and firmly fostered capital market according to the steady economy development, it may arrange better chances to privatize the state enterprises naturally.

\section{References}

An, Kwang-Il. (1994), Concept of state enterprises, Dae-myung Publication Co.

Kang, Shin-Il. (1988), Study for the Privatization of Government enterprises, Proceedings of Korea Development Institute.

Kim, Il-Sup. (1994. 1), Proposal for improving the competitions between governmental and private enterprises, Proceedings Vol. 6, Korean Institute of State Enterprises.

KOREA DEVELOPMENT INSTITUTE. (1994. 3), Scope of the policies on the promotion of the competitiveness and privatization of the government enterprises, KDI Policies Forum.

KOREA DEVELOPMENT INSTITUTE. (1994. 6), Analysis for the effect of the policies of privatizaing the government enterprises, KDI Policies Forum. 
KOREA ECONOMY INSTITUTE. (1994), Privatization and Deregulation.

MINISTRY OF FINANCE AND ECONOMY. (1994. 7), Policies on the privatization in the foreign countries.

MINISTRY OF FINANCE AND ECONOMY. (1994. 6), Examples of the privatization in the foreign countries.

MINISTRY OF FINANCE AND ECONOMY. (1994. 6), Scope of the past privatization and the plan for the future privatizatin in Korea.

Park, Heon-Jun. (1994), Method of renovating management in state enterprises, Proceedings Vol. 6, Korean Institute of State Enteprises.

PLANNING DEPARTMENT OF KOREA ELECTRIC POWER CORPORATION. (1993. 12), The actual state and the unreliability of the management in KEPCO.

Song, Dae-Hee. (1994), 1) Proposal for the policy on the management promotion in our country, Proceedings of Korea Development Institute. 2) Assessment on the past privatization of the state enterprises and proposal for the promotion, Proceedings of KDI(1995. 2).

Yu, Sung-Jae. (1994. 12), Method of renovating management in state enterprises, Proceedings Vol. 6, Korean Institute of State Enterprises.

Yu, Hoon. (1992), Concept of state enterprises, Bup-mun Publication Co.

Yoon, Sung-Sik. (1994), Concept of state enterprises, Bag-yung Publication Co. 